\title{
Investigation of the Performance Parameters of an Experimental Plate Heat Exchanger in Single Phase Flow
}

\author{
S. D. Pandey ${ }^{*}$, V. K. Nema \\ Department of Mechanical Engineering, M.N. National Institute of Technology, Allahabad, 211004, India
}

\begin{abstract}
Experiments were conducted to determine the heat transfer characteristics for fully developed flow of air and water flowing in alternate corrugated ducts. The test section was formed by three identical corrugated channels having corrugation angle of $30^{\circ}$ with cold air flowing in the middle one and hot water equally divided in the adjacent channels. Sinusoidal wavy arcs connected with tangential flat portions make the said corrugation angle with transverse direction. The Reynolds number based on hydraulic diameter varied from 750 to 3200 for water and from 566 to 2265 for air by changing the mass flow rate of the two fluids. The Prandtl numbers were approximately constant at 2.55 for water and 0.7 for air. The various correlations obtained are $\mathrm{Nu}_{\mathrm{m}}=0.247 \mathrm{Re}^{0.83}$ and $\mathrm{Nu}_{\mathrm{m}}=0.409 \mathrm{Re}^{0.57}$ for water and air, respectively and $\mathrm{f}=$ $2.014 \mathrm{Re}^{-0.12}$ for air channel.
\end{abstract}

Keywords Plate Type Heat Exchanger, Corrugated Channel, Nusselt Number, Friction Factor, Forced Convection

\section{Introduction}

Today a plate heat exchanger (PHE) is universally used in many fields; heating and ventilation, breweries, dairy, food processing, pharmaceuticals and fine chemicals, petroleum and chemical industries, power generation, offshore oil and gas production, onboard ships, pulp and paper production etc. PHEs also find applications in water to water closed circuit cooling water systems using a potentially corrosive primary cooling water drawn from sea, river, lake, or cooling tower, to cool, non-corrosive secondary liquid flowing in a closed circuit. Design theory for PHEs is given at length in reference[1], while its application was dealt in reference[2].

A compact heat exchanger has been arbitrarily defined as having an area density greater than $700 \mathrm{~m}^{2} / \mathrm{m}^{3}$ for units operating in gas streams and in excess of $300 \mathrm{~m}^{2} / \mathrm{m}^{3}$ when operating in liquid or two-phase stream[3]. The use of corrugated channel results in a more complex flow structure and improves the heat transfer by as much as two or three times compared to a conventional straight channel[4,5]. The sinusoidal wavy plate arrangements and channel geometries improved the heat transfer performance by increasing the surface area and prompting the formation of vortex in the flow $[6,7]$. The symmetric arrangement yields a superior heat transfer performance to an asymmetric arrangement. Unfortunately, the geometric parameters are not clearly expressed. Due to the high heat transfer efficiency of the plates,

* Corresponding author:

pandeyitbhumech@gmail.com (Shive Dayal Pandey)

Published online at http://journal.sapub.org/ijee

Copyright (C) 2011 Scientific \& Academic Publishing. All Rights Reserved a PHE is very compact when compared to a shell and tube heat exchanger with the same heat transfer capacity. Some of the research works on plate heat exchangers pertain to heat transfer and pressure drop characteristics of an absorbent salt solution in a commercial plate heat exchanger[7]. A Low cost route was developed to heat recovery in the Plate heat exchanger[8].

Beloborodov and Volgin[9] investigated heat transfer in a corrugated duct having an inter wall spacing and corrugation angle. The experimental apparatus is not well defined, but it appears to have been a two-fluid heat exchanger, with no direct measurement of wall temperature, such that the obtained heat-transfer coefficients are averages for the device as a whole. The corrugations were formed from sheet metal and thus could not have had the sharp-edged corrugation peaks of the present work. In light of these uncertainties, it is difficult to accord a great deal of generality to the correlations presented in[9]. The research performed by Goldstein[10] is another contribution to the literature on heat transfer in corrugated flow passages. This work was largely concerned with the low Reynolds number range from 150 to 2000, within which secondary flows were identified by high-resolution local mass-transfer measurements. The corrugated channel of[10] had only two corrugation cycles, and thus the Sherwood number results are applicable only to the region of flow development near the inlet of the corrugated duct.

A situation which has certain similarities to corrugated-duct flow is flow through tube banks, commonly encountered in heat exchangers. The similarities include periodic regions of both recirculation and forward flows. Tube-bank information $[11,12]$ will be called upon to provide 
perspective for the present Nusselt-Reynolds-Prandtl correlations.

O'Brien and Sparrow[13] conducted the trial in a corrugated duct having an inter wall spacing employing two different but complementary apparatuses, one was for heat transfer correlations and other for pressure drops. This was for only one fluid which flowed through the corrugated duct. Lin et al.[14] in their experimental work, investigated heat exchange between two fluids air and water, the former flowed through the central corrugated duct and the latter through the outer channels having one surface corrugated and other flat. Dimensional analysis was performed and the significance of various dimensionless groups determined.

Experimental work by Liu and Tsai[15] for cross corrugated channel of a small plate heat exchanger showed that the laminar flow changes to turbulent at $\operatorname{Re}>300$, while the work by Focke et al.[16] on corrugated channel for $30^{\circ}$ corrugation angle mentions the critical Re to be 400 . It was observed in the CFD model and laboratory tests $[17,20]$ that the flow was turbulent for Re in the range 600 to 1700 .

In continuation of the experimental studies an experiment was conducted for finding heat transfer coefficient and friction factor in corrugated channel. Ten wavy cycles were used against two in paper by[14]; outer channel have both surface corrugated unlike in[14] where only one surface was corrugated. The setup is described below.

\section{Fabrication of Plates}

The separate plate heat exchangers were fabricated to make horizontal channels formed by corrugated plates in the front view as sketched in Figure 1.

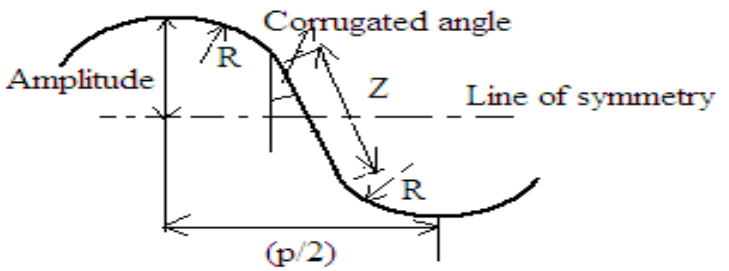

Figure 1. Geometry of a plate segment.

The dimensions of the PHEs are given in the following table.

\begin{tabular}{|c|c|}
\hline System & Water-Air \\
\hline Pitch $(\mathrm{p})$ & $70.0 \mathrm{~mm}$ \\
\hline Amplitude $(\lambda)$ & $12.0 \mathrm{~mm}$ \\
\hline Straight length segment $(\mathrm{Z})$ & $11.6 \mathrm{~mm}$ \\
\hline Radius of curvature $(\mathrm{R})$ & $14.0 \mathrm{~mm}$ \\
\hline Corrugation angle from normal to the plate surface & $30^{\circ}$ \\
\hline
\end{tabular}

The above-mentioned dimensions were obtained by making a wooden pattern in the carpentry shop and then giving the required shape to the sheets using the pattern.

\section{Experimental Setup}

The experimental setup, described schematically in the
Figure 2 is fabricated to investigate the heat transfer characteristics in a plate heat exchanger having three identical channels formed by Galvanized Iron corrugated plates of 24 gauge.

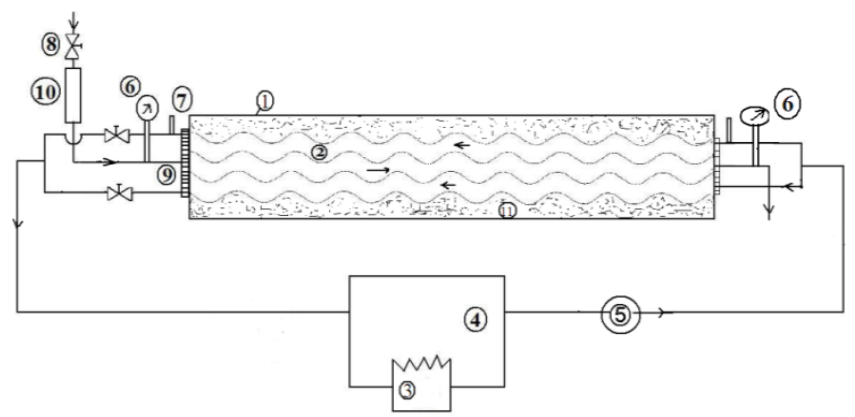

[1-GI sheet case, 2-Fluid channel, 3-Water heater, 4-Water container, 5-Water pump,6-Pressure gauge, 7-Thermometer, 8-Control valve, 9-Flow straightener, 10-Rotameter, 11-Insulated chamber]

Figure 2. Schematic of the experimental setup.

A flow straightener is installed at the entrance of the test section to maintain the inlet flow uniform. The basic components, as numbered in the schematic and their names given along with the caption, of the experimental apparatus include a water loop, an air loop, and a measurement system. The water loop comprises a water tank containing a heater, a pump and a temperature controller. Its flow rate is measured by noting time for collection of fixed volume. The components in the water system are thermally insulated and water flow rate is adjusted to give a fairly constant bulk temperature along the channel. The air loop consists of a blower, a rotameter, the corrugated channel, and a number of valves which enable the flow rate to be adjusted at a few selected values.

\subsection{Specifications of the Experimental Setup}

Length of the test section $=70 \mathrm{~cm}$

Width of the test section $=11 \mathrm{~cm}$

Height of the test section $=25 \mathrm{~cm}$

Developed length of the corrugated plate $=82 \mathrm{~cm}$

Gap between two corrugated plates $=5 \mathrm{~cm}$

Dimensions of the water container $=30 \mathrm{~cm} \times 30 \mathrm{~cm}$

\subsection{Experimental Procedures}

During experiments, hot water was made to flow through the two outer corrugated channels to maintain the channel surfaces at an approximately constant temperature. Thermocouples wrapped in copper tubes and inserted in the front cover plate of the test section were used to record the bulk temperature of air and water. The side effect was negligible due to small aspect ratio of the channels and thus the variations in the transverse direction of a channel could be neglected. In the experiments, the temperature distribution in the horizontal middle planes of the channels was measured using thermocouples positioned at 19 different locations along the length of the channels in the water- and air-loop with 3 and half digit potentiometer. The temperatures of the inlet and 
outlet air and water were measured with mercury-in-glass thermometers. The pressures of the air at the inlet and outlet of the test section were measured with the pressure gauges[21]. Experiments were conducted with Reynolds number varying between 566 to 2265 for air and 750 to 3200 for water by varying their flow rates. Nusselt number and friction factor were then determined.

\section{Numerical Methodology}

Assuming heat loss to the surroundings to be negligible, heat transfer rate across an elemental heat exchanger is given by,

$$
\delta \mathrm{Q}=\mathrm{mc}_{\mathrm{p}}\left[\left(\mathrm{T}_{\mathrm{b}, \mathrm{x}+\mathrm{dx}}-\mathrm{T}_{\mathrm{b}, \mathrm{x}}\right]\right.
$$

Local heat transfer coefficients for air are expressed as:

$h_{c, x}=m_{c} c_{p, c}\left[\left(T_{b, x+d x}-T_{b, x}\right]_{c} /\left[\left(T_{w}-T_{b}\right)_{c} d A_{s}\right]\right.$, where the mean bulk temperature for the element is given by

$$
\begin{aligned}
& \mathrm{T}_{\mathrm{b}}=\left(\mathrm{T}_{\mathrm{b}, \mathrm{x}}+\mathrm{T}_{\mathrm{b}, \mathrm{x}+\mathrm{dx}}\right)_{\mathrm{c}} / 2 \text {; Therefore, it can be shown that } \\
& \begin{aligned}
\mathrm{Nu}_{\mathrm{c}, \mathrm{x}} & =\mathrm{h}_{\mathrm{c}, \mathrm{x}} \mathrm{D}_{\mathrm{h}} / \mathrm{k} \\
& =\mathrm{m}_{\mathrm{c}} \mathrm{c}_{\mathrm{p}, \mathrm{c}}\left[\left(\mathrm{T}_{\mathrm{b}, \mathrm{x}+\mathrm{dx}}-\mathrm{T}_{\mathrm{b}, \mathrm{x}}\right]_{\mathrm{c}} /\left[\left(\mathrm{T}_{\mathrm{w}}-\mathrm{T}_{\mathrm{b}}\right)_{\mathrm{c}} \mathrm{dA} \mathrm{A}_{\mathrm{s}}\right] . \mathrm{k} .\right]
\end{aligned}
\end{aligned}
$$

The local heat transfer coefficient and Nusselt number for the hot fluid (water) can be calculated using the same procedure. Next the hydraulic radius and various dimensionless numbers for a heat exchanging fluid are obtained as given below. Suffixes pertaining to the hot and cold fluid can be added suitably to variables.

Where $D_{\mathrm{h}}=4 . \mathrm{A}_{\mathrm{o}} / \mathrm{P}$,

$$
\operatorname{Re}=\left(\rho . V \cdot D_{h} / \mu\right) .
$$

$\mathrm{A}_{\mathrm{o}}=\mathrm{W} \times \mathrm{H}, \mathrm{P}=2(\mathrm{~W}+\mathrm{H})$,

and flow velocity, $\mathrm{V}=\mathrm{m} /\left(\rho \mathrm{A}_{\mathrm{o}}\right)$

Prandtl number, $\operatorname{Pr}=\left(\mu \cdot c_{\mathrm{p}}\right) / \mathrm{k}$

The effectiveness of the PHE is calculated from experimental observations.

$$
\mathrm{C}=\mathrm{C}_{\mathrm{h}}\left(\mathrm{T}_{\mathrm{h}, \mathrm{i}}-\mathrm{T}_{\mathrm{h}, \mathrm{o}}\right) /\left[\mathrm{C}_{\min }\left(\mathrm{T}_{\mathrm{h}, \mathrm{i}}-\mathrm{T}_{\mathrm{c}, \mathrm{i}}\right)\right]
$$

The pressure drop $\Delta \mathrm{p}_{\mathrm{h}}$ and $\Delta \mathrm{p}_{\mathrm{c}}$ on hot and cold fluid sides are calculated from experimental observations and theoretical formulae as given below.

Pressure drops for the fluids,

$$
\Delta \mathrm{p}_{\mathrm{h}}=\left(\mathrm{p}_{\mathrm{h}, \mathrm{i}}-\mathrm{p}_{\mathrm{h}, \mathrm{o}}\right) ; \Delta \mathrm{p}_{\mathrm{c}}=\left(\mathrm{p}_{\mathrm{c}, \mathrm{i}}-\mathrm{p}_{\mathrm{c}, \mathrm{o}}\right)
$$

Friction factor $\mathrm{f}$ is found form the following relationship:

$$
\mathrm{f}=\Delta \mathrm{p} /\left[\left(\mathrm{L} / \mathrm{D}_{\mathrm{h}}\right) \cdot\left(\mathrm{G}^{2} / 2 \cdot \rho \cdot \mathrm{g}_{\mathrm{c}}\right)\right]
$$

Experimentally obtained values of Nusselt and friction factor may be compared with the following correlations, available in the literature.

(i) Focke correlations[1] for

a) Mean Nusselt number $\left(\mathrm{Nu}_{\mathrm{m}}\right)$ is given below:

Corrugated plates with plate corrugation angle $\beta=30^{\circ}$ :

$\mathrm{Nu}_{\mathrm{m}}=\mathrm{j}_{\mathrm{cp}} \cdot \operatorname{Re} \cdot \operatorname{Pr}^{1 / 3}\left(\mu_{\mathrm{w}} / \mu\right)^{\mathrm{n}}$

where $\mathrm{j}_{\mathrm{cp}}=0.80 \mathrm{Re}^{-0.477}$ (for $100<\mathrm{Re}<1000$ )

$\mathrm{j}_{\mathrm{cp}}=0.2334 \operatorname{Re}^{-0.297}$ (for $1000<\operatorname{Re}<5 \times 10^{4}$ )

The exponent $\mathrm{n}$ for the wall viscosity ratio is equal to -0.2 .

b) Friction factor ( $\mathrm{f}$ ) is given below:

$\mathrm{f}=\mathrm{f}_{\mathrm{cp}} \cdot\left(\mu_{\mathrm{w}} / \mu\right)^{\mathrm{m}}$ where

$\mathrm{f}_{\mathrm{cp}}=0.287 \mathrm{Re}^{-0.147}\left(\right.$ for $\left.3000<\operatorname{Re}<10^{4}\right)$
The exponent $\mathrm{m}$ for the wall viscosity correlation is given by:

$\mathrm{m}=0.3 /(\operatorname{Re}+0.04)^{0.25}$

(ii) The Dittus-Boelter equation[4] for constant wall temperature turbulent flow in a circular tube; is given by

$$
\mathrm{Nu}_{\mathrm{m}}=0.023 \operatorname{Re}^{0.8} \operatorname{Pr}^{0.4}
$$

(iii) The Brien and Sparrow[13] correlation for water is given by $\mathrm{Nu}=0.409 \mathrm{Re}^{0.614} \mathrm{Pr}^{0.34}$ for $1500<\mathrm{Re}<25000$ and 4 $<\operatorname{Pr}<8$ for flow in a triangular wavy channel with corrugation angle $30^{\circ}$.

(iv) Cooper and Usher[18] gave the correlation $\mathrm{Nu}=0.4 \mathrm{Re}^{0.64} \operatorname{Pr}^{0.4}$ for small size chevron plates.

\section{Results and Discussion}

\begin{tabular}{|c|c|c|c|c|c|}
\hline \multicolumn{3}{|c|}{$\begin{array}{c}\text { Air Channel (flow rate }=200 \\
\text { lpm) } \\
\text { Manometric level differ- } \\
\text { ence }\left(\Delta \mathrm{z}_{\mathrm{i}}-\Delta \mathrm{z}_{\mathrm{o}}\right)=1.5 \mathrm{~cm} \text { of } \mathrm{H}_{2} \mathrm{O}\end{array}$} & \multicolumn{3}{|c|}{$\begin{array}{c}\text { Water Channel (flow rate }=0.244 \\
\mathrm{~kg} / \mathrm{s})\end{array}$} \\
\hline $\begin{array}{l}\text { Distance } \\
\text { from left } \\
\text { end(x) } \\
\text { mm }\end{array}$ & $\begin{array}{l}\text { Local } \\
\text { Tem- } \\
\text { pera- } \\
\text { ture } \\
\left(\mathrm{T}_{\mathrm{x}}\right)^{\circ} \mathrm{C}\end{array}$ & $\begin{array}{l}\text { Bulk } \\
\text { Tem- } \\
\text { pera- } \\
\text { ture } \\
\left(\mathrm{T}_{\mathrm{b}}\right)^{\circ} \mathrm{C}\end{array}$ & $\begin{array}{l}\text { Distance } \\
\text { from right } \\
\text { end(x) } \\
(\mathrm{mm})\end{array}$ & $\begin{array}{l}\text { Local } \\
\text { Tem- } \\
\text { perature } \\
\left(\mathrm{T}_{\mathrm{x}}\right)^{\circ} \mathrm{C}\end{array}$ & $\begin{array}{l}\text { Bulk } \\
\text { Tem- } \\
\text { pera- } \\
\text { ture } \\
\left(\mathrm{T}_{\mathrm{b}}\right)^{\circ} \mathrm{C}\end{array}$ \\
\hline 0 & 44.000 & & 0 & 71.000 & \\
\hline 40 & 44.950 & 44.475 & 70 & 70.549 & 70.774 \\
\hline 140 & 49.775 & 47.362 & 170 & 70.352 & 70.451 \\
\hline 180 & 51.625 & 50.700 & 270 & 70.301 & 70.326 \\
\hline 280 & 52.625 & 52.125 & 360 & 70.235 & 70.268 \\
\hline 320 & 54.450 & 53.537 & 410 & 69.784 & 70.009 \\
\hline 420 & 54.750 & 54.600 & 510 & 69.745 & 69.764 \\
\hline 460 & 55.975 & 55.362 & 610 & 69.509 & 69.627 \\
\hline 560 & 60.375 & 58.175 & 700 & 69.000 & 69.254 \\
\hline
\end{tabular}

Experiments were conducted with Reynolds number varying between 566 to 2265 for air and 750 to 3200 for water by varying the flow rates of the fluids. Nusselt number and friction factor were then determined.

The observations for the typical combination of air- and water-flow rates for counter flow are given in Table 1.

Table 1. Observations for a typical combination of air- and water-flow rates for counter flow.

Additional observations are the average wall temperatures, from right to left, at three locations which are found as $64.75^{\circ} \mathrm{C}, 63.69^{\circ} \mathrm{C}$ and $59.98^{\circ} \mathrm{C}$.

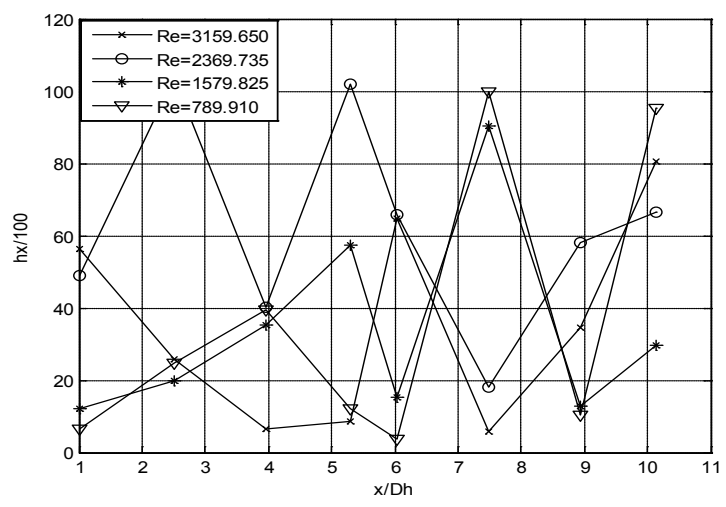

Figure 3. Variation of $h_{x}$ along channel length (For water). 
The variation of local heat transfer coefficient along channel length $\left(x / D_{h}\right)$ is shown in Figure 3 for water and Figure 4 for air.

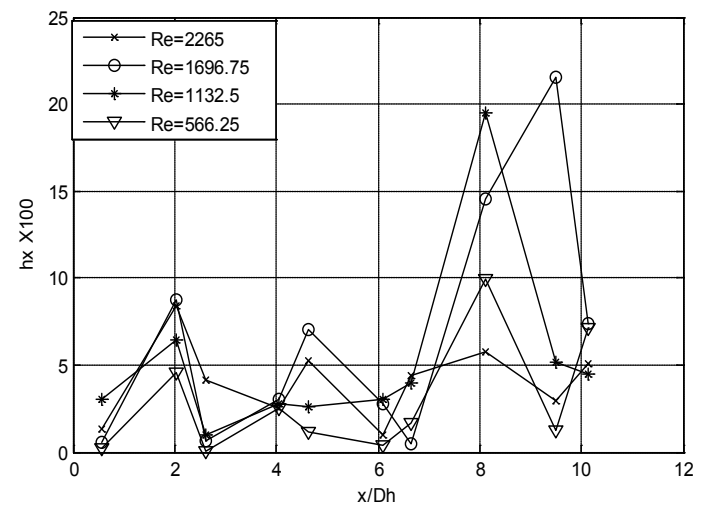

Figure 4. Variation of $h_{x}$ along channel length (For Air).

For both the fluids, it is seen that $h_{x}$ attains a local peak at the individual crests of the channel surface. This result is very different from that observed in a straight duct.

Further, the maximum value occurs at a crest in the vicinity of $x / D_{h}=8$, for all Reynolds numbers involved, where the irreversibility is expected to be the least as the temperature difference between donor and recipient is least. This result is very different from that observed in the straight duct, in which case the $h_{x}$ converges to a constant value within the fully developed region.

\subsection{Nusselt Number}

The mean heat transfer coefficient varied from 162.73 $\mathrm{W} / \mathrm{m}^{2} \mathrm{~K}$ to $204.18 \mathrm{~W} / \mathrm{m}^{2} \mathrm{~K}$ and hence $\mathrm{Nu}_{\mathrm{m}}$ varied from 15 to 33 for air. Corresponding values for water were 633.42 $\mathrm{W} / \mathrm{m}^{2} \mathrm{~K}, 2029.17 \mathrm{~W} / \mathrm{m}^{2} \mathrm{~K}, 65$ and 210 . The variation of average Nusselt number, $\mathrm{Nu}_{\mathrm{m}}$ with Reynolds number is given in Figures 3 and 4 for the two fluids.

The experimental data has been compared with those calculated using the Dittus-Boelter equation for constant wall temperature for smooth tubes, and Brien \& sparrow[13], Cooper and Usher[18] and Focke[1] correlations for corrugated plates. While comparing with Focke[1] correlation it is assumed that the correlation for $\mathrm{Nu}_{\mathrm{m}}$ and $\mathrm{f}$ which are valid up to $\operatorname{Re}=50000$ and 10000 , respectively.

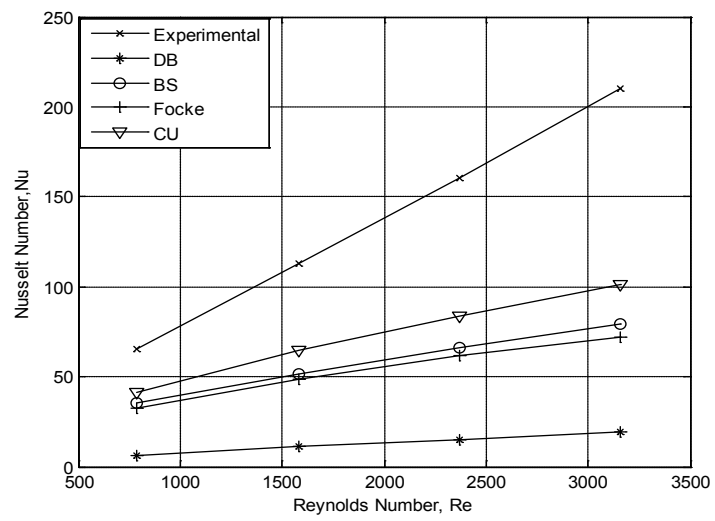

Figure 5. Comparison of experimental and theoretical Nusselt numbers (For Water).
Comparison of experimental and theoretical mean Nusselt numbers with Reynolds number for water is shown in Figure 5. The experimental results have the same trend as the calculated values for air from using the Dittus-Boelter equation for constant wall temperature and Brien and sparrow, Cooper and Usher, and Focke correlations for corrugated plate.

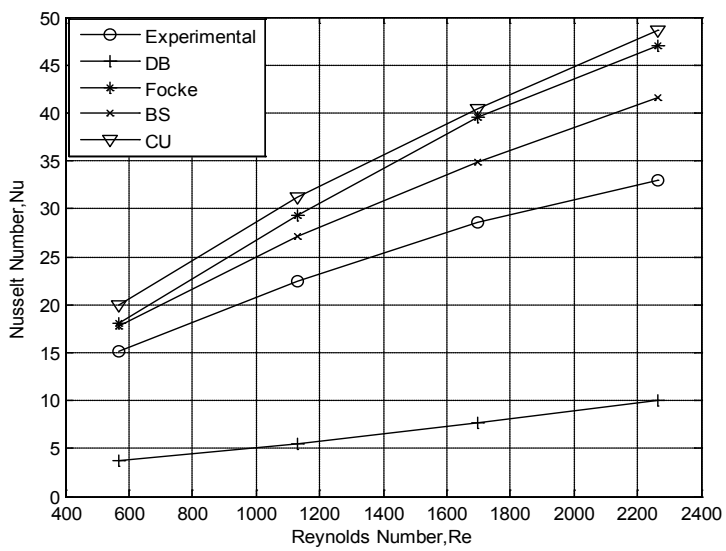

Figure 6. Comparison of experimental and theoretical Nusselt numbers (For Air).

However, the experimental Nusselt number is highest at a given Reynolds number. It means that none of the existing correlations is able to predict real Nusselt number for the case under consideration. It is worthwhile to find a correlation for the case under consideration for Nusselt number with Reynolds number for water. The correlation is $\mathrm{Nu}_{\mathrm{m}}=0.247 \mathrm{Re}^{0.83}$. Variation of Nusselt number for air is drawn in Figure 6 and the correlation found is $\mathrm{Nu}_{\mathrm{m}}=0.409 \mathrm{Re}^{0.57}$.

\subsection{Friction Factor}

Experimental friction factor was compared with the values obtained using Focke and Kumar correlations and the comparison is shown in Figure 7. Theoretical friction factor using Kumar empirical correlation[19] is also included in this Figure.

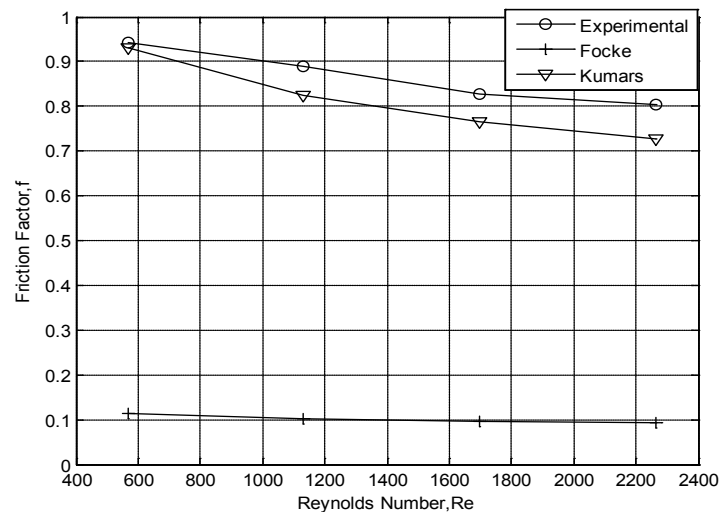

Figure 7. Comparison of experimental and theoretical friction factor (For Air).

Figure 7 shows that the friction factor (f) decreases with increase in Reynolds number because it is inversely proportional to square of velocity and hence of Reynolds number. 
The values of $f$ for the experiment are closer to Focke correlations and much lower than Kumar correlation. The friction factor varied from 0.803 to 0.943 for air. The correlation of friction factor for air, using experimental values, is found as $\mathrm{f}=2.014 \mathrm{Re}^{-0.12}$.

\subsection{Effectiveness}

Effectiveness of this experimental corrugated PHE was found as $81 \%$.

\section{Goodness of Fit for Various Curves}

The calculated in terms of the following statistical parameters namely, Standard deviations (s) and Square of the correlation coefficient $\left(\mathrm{r}^{2}\right)$, defined by

$$
\begin{gathered}
s=\sqrt{\frac{\sum\left(y_{i}-\bar{y}\right)^{2}}{(n-1)}}, \text { and } \\
r^{2}=1-\frac{\sum\left(y_{i}-y_{i p}\right)^{2}}{\sum\left(y_{i}-\bar{y}\right)^{2}}=1-\frac{\operatorname{norm}(d, 2)^{2}}{(n-1) s^{2}}
\end{gathered}
$$

Values of $\mathrm{s}$ and $\mathrm{r}^{2}$ for Nusselt number $\mathrm{Nu}_{\mathrm{m}}$ are 0.3386 and 0.9997 , respectively and those for friction factor $\mathrm{f}$ are 0.0723 and 0.998 , respectively.

\section{Uncertainty of Measurements}

Estimate of experimental errors on the local Nusselt number $\left(\mathrm{Nu}_{\mathrm{x}}\right)$, effectiveness $(\mathrm{c})$, and friction factor (f) associated with the use of equation (2), (5) and (6) was conducted taking into account the uncertainties $(\sigma)$ associated with each of the independent variables.

The uncertainty $\mathrm{W}_{\mathrm{R}}^{+}$, arising in calculating a result $\mathrm{R}^{+}$ due to several independent variables, is given as follows;

$$
W_{R^{+}}=\left(\left(\frac{\delta R^{+}}{\delta X_{1}} w_{1}\right)^{2}+\left(\frac{\delta R^{+}}{\delta X_{2}} w_{2}\right)^{2}+\cdots . .+\left(\frac{\delta R^{+}}{\delta X_{n}} w_{n}\right)^{2}\right)^{1 / 2}
$$

where the result $\mathrm{R}^{+}$is a given function of the independent variables $\mathrm{X}_{1}, \mathrm{X}_{2}, \ldots \mathrm{X}_{\mathrm{n}}$ and $\mathrm{w}_{1}, \mathrm{w}_{2}, \ldots \mathrm{w}_{\mathrm{n}}$ are uncertainties in the independent variables[20]. Uncertainty calculations showed maximum value of $2.8,5.3,4.0$, and $6.4 \%$ in results for Reynolds number, Nusselt number, Prandtl number and friction factor, respectively. The individual contributions to the uncertainties of the non-dimensional parameters, for each of the measured physical properties are summarized in Table 2 .

Table 2. Typical uncertainties for relevant variable.

\begin{tabular}{|c|c|c|}
\hline Sl. No. & Variable & Uncertanity(\%) \\
\hline 1. & Hot fluid inlet temperature, $\mathrm{T}_{\mathrm{h}, \mathrm{i}}$ & \pm 0.1 \\
\hline 2. & Hot fluid outlet temperature, $\mathrm{T}_{\mathrm{h}, \mathrm{o}}$ & \pm 0.1 \\
\hline 3. & Cold fluid inlet temperature, $\mathrm{T}_{\mathrm{c}, \mathrm{i}}$ & \pm 0.1 \\
\hline 4. & Cold fluid outlet temperature, $\mathrm{T}_{\mathrm{c}, \mathrm{o}}$ & \pm 0.1 \\
\hline 5. & Inner wall temperature, $\mathrm{T}_{\mathrm{w} 1}$ & \pm 0.1 \\
\hline 6. & outer wall temperature, $\mathrm{T}_{\mathrm{w} 2}$ & \pm 0.1 \\
\hline 7. & Ambient temperature, $\mathrm{T}_{\mathrm{e}}$ & \pm 0.1 \\
\hline 8. & Hydraulic diameter, $\mathrm{D}_{\mathrm{h}}$ & \pm 1.2 \\
\hline 9 & Pressure difference, $\Delta \mathrm{p}$ & \pm 2.5 \\
\hline 10. & Water mass flow rate, $\mathrm{m}$ & \pm 2.5 \\
\hline
\end{tabular}

\section{Nomenclature}

A

C

$\mathrm{C}_{\mathrm{p}}$

$\mathrm{D}_{\mathrm{h}}$

$\mathrm{f}$

$\mathrm{H}$

$\mathrm{h}$

j

$\mathrm{k}$

L

1

$\mathrm{m}$

$\mathrm{Nu}$

$\mathrm{p}$

$P$

$\operatorname{Pr}$

Q

$\mathrm{Re}$

$\mathrm{T}$

W

$\mathrm{V}$

Z

$\mu$

$\beta$

$\rho$

C
Area, $\mathrm{m}^{2}$

Heat capacity rate, $\mathrm{kJ} \mathrm{s}^{-1} \mathrm{~K}^{-1}$

Specific heat at constant pressure, $\mathrm{kJ} \mathrm{kg}^{-1} \mathrm{~K}^{-1}$

Hydraulic diameter, $m$

Friction factor

Height of flow channel, $m$

heat transfer coefficient, $\mathrm{W} \mathrm{m}{ }^{-2} \mathrm{~K}^{-1}$

Colburn factor

Thermal conductivity, $\mathrm{W} \mathrm{m}^{-1} \mathrm{~K}^{-1}$

Projected length of the channel, $m$

Developed length of the channel, $m$

Mass flow rate, $\mathrm{kg} \mathrm{s}^{-1}$

Nusselt number

Pressure, $\mathrm{Pa}$

Wetted perimeter, $\mathrm{m}$

Prandtl number

Heat transfer rate, $\mathrm{kW}$

Reynolds number

Temperature, ${ }^{\circ} \mathrm{C}$

Channel width, $\mathrm{m}$

Flow velocity, $\mathrm{ms}^{-1}$

Manometric height, $\mathrm{m}$

Viscosity of air, $\mathrm{N} \mathrm{s} \mathrm{m}^{-2}$

Corrugation angle, deg.

Density, $\mathrm{kg} \mathrm{m}^{-3}$

Effectiveness

\section{Suffixes}

b Bulk

c cold fluid

cp Constant property (i.e. variation of viscosity from wall to bulk ignored)

h Hot fluid

i inlet

m Mean value

min Minimum

o Outlet, flow

s Surface

w Wall

$\mathrm{x}$ Location along the channel from inlet of the fluid

\section{Prefix}

$\mathrm{d}, \delta \quad$ Elemental

\section{Conclusions}

The test section was formed by three identical corrugated channels having corrugation angle of $30^{\circ}$ with cold air flowing in the middle one and hot water equally divided in the adjacent channels. Sinusoidal wavy arcs connected with tangential flat portions make the corrugation angle with transverse direction. The Reynolds number based on hydraulic diameter varied from 750 to 3200 for water and from 566 to 2265 for air the inlet Prandtl numbers for both 
the fluid were approximately constant. Experimental investigations are done by changing the mass flow rate of air and water. The pressure drop and heat transfer characteristics in the corrugated channel of a plate heat exchanger were found. Dimensionless correlations for $\mathrm{Nu}_{\mathrm{m}}$ have been developed for both air and water, and friction factor for air only, for volume flow rates $200 \mathrm{lpm}, 150 \mathrm{lpm}, 100 \mathrm{lpm}, 50 \mathrm{lpm}$ of air and mass flow rates $0.244 \mathrm{~kg} / \mathrm{s}, 0.1533 \mathrm{~kg} / \mathrm{s}, 0.1022 \mathrm{~kg} / \mathrm{s}$, $0.0511 \mathrm{~kg} / \mathrm{s}$ of water, based on experimental results. It is found that $\mathrm{Nu}_{\mathrm{x}}$ depends on $\mathrm{Re}$ and $\mathrm{x} / \mathrm{D}_{\mathrm{h}}$. Friction factor was found to depend on Re. The magnitudes of the $\mathrm{Nu}_{\mathrm{m}}$ and friction factor are high when compared to conventional pipe flows. The mean heat transfer coefficient varied for air from $162.73 \mathrm{~W} / \mathrm{m}^{2} \mathrm{~K}$ to $204.18 \mathrm{~W} / \mathrm{m}^{2} \mathrm{~K}$ and hence $\mathrm{Nu}_{\mathrm{m}}$ varied from 15 to 33. Corresponding values for water were $633.42 \mathrm{~W} / \mathrm{m}^{2} \mathrm{~K}, 2029.17 \mathrm{~W} / \mathrm{m}^{2} \mathrm{~K}, 65$ and 210 . Correlations found for Nusselt numbers are $\mathrm{Nu}_{\mathrm{m}}=0.247 \mathrm{Re}^{0.83}$ for water a $\mathrm{Nu}_{\mathrm{m}}=0.409 \mathrm{Re}^{0.57}$ for air. Similarly the friction factor varied from 0.803 to 0.943 for air and the correlation for its friction factor was found as $\mathrm{f}=2.014 \mathrm{Re}^{-0.12}$. Effectiveness of this experimental corrugated PHE was found as $81 \%$.

\section{REFERENCES}

[1] Shah, R. K., Focke, W. W., 1988, Plate heat exchangers and their design theory, Heat transfer equipment design, Hemisphere Publishing Corporation, pp. 227-254

[2] Mehta, S. K., 1988, Heat Exchanger in heavy water reactor system, Heat transfer equipment design, Hemisphere Publishing Corporation, pp. 337-349

[3] Reay, D. A., 2004, Compact Heat Exchangers, Enhancement and Heat Pump. Int. J. of Refrigeration, 25, 460-470

[4] Incorpera, F. P., and Dewitt, P. D., Fundamentals of Heat Transfer, John Wiley and Sons; V Ed, 2004

[5] Goldstein, L. Jr, Sparrow, E. M., 1977, Characteristics for Flow in Channel. Int. Heat transfer; 05: 205-209

[6] Nishimura, T., Murakami, S., Arakawa, S., Kawamura, Y., 1990, Flow observations mass transfer characteristics in symmetrical wavy walled channel at moderate Reynolds numbers for steady flow., Int. J. Heat Mass Transfer, 33, $835-845$

[7] Warnakulasuriya, F. S. K., Worek, W. M., 2008, Heat Transfer and Pressure Drop Properties of High Viscous Solutions in Plate Heat Exchangers., Int. J. of Heat and Mass Transfer,
$1(51), 52-67$

[8] Lamb, B. R., 1982, Plate Heat Exchangers - A Low-Cost Route to Heat Recovery, Heat Recovery Systems, 2(3), 247-255.

[9] Beloborodov, V. G., Volgin, B.P., 1971, Heat Transfer and Pressure Drop in Heat Transfer Equipment with Slot Channels of Varying Cross Section., International Chemical Engineering, 11, 229-233

[10] Goldstein, Leonardo Jr., Sparrow, E. M., 1977, Heat and Mass Transfer Characteristics for Flow in a Corrugated Wall Channel., ASME journal of heat transfer, 91, 187-195.

[11] Zhukauskas, A., 1972, Heat Transfer from Tubes in Cross flow., Advances in Heat Transfer, 8, 93-160

[12] Grimison, E. D., 1937, Correlation and Utilization of New Data on Flow of Gases over Tube Banks. Trans., ASME, 59, 583-594

[13] Brien, J. E. O., Sparrow, E. M., 1982, Corrugated-Duct Heat Transfer, Pressure Drop, and Flow Visualization., ASME journal of heat transfer, 104, 410-416

[14] Lin, J. H., Huang, C. Y., Su, C. C., 2007, Dimensional Analysis for the Heat Transfer Characteristics In The Corrugated Channels of Plate Heat Exchangers., International Communications in Heat and Mass Transfer, 34, 304-312

[15] Liu, F. B., Tsai, Y. C., 2009, An experimental and numerical investigation of fluid flow in a cross corrugated channel., Applied Thermal engineerin, 4, 207- 214

[16] Focke, W. W., Knibbe, P. G., 1986, Flow visualization in parallel plate duct with corrugated wall. J. Fluid Mechanical, $165,73-77$

[17] Tsa, Y. C., Liu, F. B., Shen, P. T., 2009, Investigation of the pressure drop and flow distribution in a chevron-type plate heat exchanger. International communications in heat and mass transfer, 36, 574-578

[18] Cooper, A., Usher, J. D., Friction Factor Correlations. HemisphereHandbook of Heat Exchanger Design, G. F. Hewitt Co., Hemisphere, Washington DC,1990

[19] Kakac, S., Liu, H., Heat Exchangers: Selection, Rating and Thermal Design. CRC, Washington, DC, Chap. 10, 2002

[20] Pandey, S. D., Nema, V. K., 2011, An experimental investigation of exergy loss reduction in corrugated plate heat exchanger. Energy, 36 (5), 2997-3001

[21] Pandey, S. D,. Nema, V. K., 2011, Experimental investigation of heat transfer and friction factor in a corrugated plate heat exchanger. International Journal of Energy and Environment, 2( 2),287-296 